\title{
THE EFFECT OF HEATING TEMPERATURE ON THE HARDNESS, MICROSTRUCTURE AND V-BENDING SPRING BACK RESULTS ON COMMERCIAL STEEL PLATE
}

\author{
Asep Ruchiyat ${ }^{1}$, Muh Anhar ${ }^{2}$, Yusuf $^{3}$, Betti Ses Eka Polonia ${ }^{4}$ \\ Politeknik Negeri Ketapang \\ as3p78@gmail.com¹, anhar_dol@yahoo.com², yusufpolitap@gmail.com³ \\ bettipolonia@politap.ac.id ${ }^{4}$
}

\begin{abstract}
The need for low carbon steel plate sheets with relatively thin thickness measurements in Indonesia is currently quite high, especially in supporting the automotive industry, the electronics industry, the food industry, beverages, and household appliances. To fulfill this, raw materials for low carbon steel plate sheets that have high formability and are not easily cracked in critical areas of the desired model are required. For this reason, research on the effect of temperature variations in heat treatment on hardness, microstructure and spring back of V-bending results on steel plates with a plate thickness of $0.8 \mathrm{~mm}$. The research method used was a laboratory experimental method. The heat treatment is carried out with temperature variations of 710,820 and $930^{\circ} \mathrm{C}$ with a holding time of 60 minutes. Tests carried out on specimens are hardness testing, microstructure testing, and spring back Vbending results on steel plates. The results of this study indicate a decrease in the spring back angle where the smallest spring back angle in the bending process is on the $930^{\circ} \mathrm{C}$ plate which is 1,040 . The value of the hardness results from V-bending has increased significantly. The increase in the value of hardness because the plate has an atom shift or dislocation by shear stress (slip) due to plastic deformation on the plate. The highest hardness value is on the $710^{\circ} \mathrm{C}$ plate which is $154.67 \mathrm{HV}$ or has an increase of $14,291 \%$ of the pre-bending plate. The lowest hardness value is on the $930^{\circ} \mathrm{C}$ plate which is $125.33 \mathrm{HV}$, its hardness increases $4.4 \%$ against the pre-bending plate. Heat treatment also causes changes in the microstructure of the plates from the process of regulation and reshaping of crystals to the growth of new grains which have implications for changes in mechanical properties and formability of the workpiece.
\end{abstract}

Keywords: Sheet Metal Forming, V-Bending, Springback, Annealing, Microstructure

\section{INTRODUCTION}

The need for low carbon steel plate sheets with relatively thin thickness measurements in Indonesia is quite high, especially in supporting the automotive industry, the electronics industry, the food and beverage industry, household appliances. For this reason, steel sheet sheets that have good mechanical properties are seen from each function.

In the process of pressing/stamping known as sheet metal forming which is the process of forming which aims to make the plate or material undergo plastic deformation so that it forms components of the desired design. The use of sheet metal forming is an effective forming technique because it can replace the machining and welding process. Bending is one of the sheet metal forming processes that are often used, but many problems occur with the results of the bending process, depending on the choice of the bending method, dies design, machine setup and process parameters such as minimum bending radius, spring back, material conditions, and microstructure material.

All materials have a limited elastic modulus, plastic deformation will be followed by the elastic properties of the material. When bending is removed there will be a change in shape or deviation of the die surface used for pressure, this is because the plate has elastic properties so that some of the deformations will return a little to a certain point. Deviation in shape and size due to the elasticity of this material is known as spring back. In practice spring back can be reduced by overbending, ie the bending angle is smaller than required.

Ozturk F et al, (2009) investigated the effect of cold and hot spring back temperature on aluminum alloy magnesium $5083-\mathrm{H} 111$ by using the warm forming method. The problem underlying this research is to reduce automotive weight in increasing fuel efficiency and reducing vehicle emissions. In this case spring back analysis of hardening of the specimen with a thickness of $3 \mathrm{~mm}$ and an angle of $60^{\circ}$ uses the die $\mathrm{V}$-bending process while the temperature variations are -50 to $300^{\circ} \mathrm{C}$. The results of this experiment are that spring back increases at 
temperatures of 0.25 and $100^{\circ} \mathrm{C}$ and then decreases above $200^{\circ} \mathrm{C}$. The lowest spring back is obtained at $300^{\circ} \mathrm{C}$.

Low carbon steel has $\leq 0.30 \%$ carbon. Generally supplied as flat-rolled products (sheet or strip), in cold-rolled and annealed condition. For high-formability steels, carbon content is less than $0.1 \%$ with $0.4 \%$ magnesium content, used for automobile body panels, thin plates, and wire products. For rolled steel structural plates and sections, the carbon content is $0.3 \%$ with a magnesium content of $1.5 \%$, used for stampings, forgings, seamless tubes, and boilerplates (Mubarok, 2008).

Previously, has been described several problems that occur in the plate bending process, then this raises research questions that will be studied and analyzed in this study is how the influence of annealing heating temperature on hardness, microstructure, and spring back, the results of V-bending of commercial steel plates.

To simplify the analysis, several limitations are needed, including:

1. The bending machine used is a tensile-press testing machine.

2. The material used is commercial steel plates with uniform dimensions.

3. The shape of the workpiece made is v-bending with an angle of 900 .

4. Temperature variations used are 710,820 and $930^{\circ} \mathrm{C}$.

5. The holding time is 60 minutes.

6. The workpiece is cooled to a temperature in a heating furnace.

7. Testing is done by micro vickers hardness test.

The research objectives to be achieved are

1. To determine the value of the surface hardness of the V-bending results in the test material before and after the annealing process is treated.

2. To determine the microstructure of the V-bending results in the test material before and after the annealing process is carried out.

3. To find out the occurrence of the spring back phenomenon in the V-bending process.

Referring to the research objectives, this research is expected to provide at least 3 contributions, namely:

1. Provide information in the form of a behavior database of the influence of annealing heating temperature on spring back, hardness and microstructure resulting from $\mathrm{V}$-bending of commercial steel plates.

2. For academics, as a study and comparison in conducting studies on research on the effect of annealing temperature on the bending process of commercial steel plates.

3. From a practical point of view, the results of this study are expected to be a reference for similar research in the future, especially in the field of sheet metal forming.

\section{LITERATURE REVIEW}

Keum et al, (2002) conducted a study entitled Springback of FCC Sheet in Warm Forming, using a warm forming method to change the material properties of aluminum to reduce spring back. The background of this research is to find the desired material and mechanical properties in the theoretical nature of the spring back phenomenon on aluminum sheet metal, Al5052 and Al1050 with $0.8 \mathrm{~mm}$ thickness specimens under warm forming conditions. Each specimen was arranged 00, 450, and 900. Tests were at a temperature of 18 $350^{\circ} \mathrm{C}$, a holding time of 30 minutes and a speed of $5 \mathrm{~mm} / \mathrm{min}$. Then the specimen is analyzed by the tensile test and chemical composition test. The results of this study, during the formation of warm forming at a temperature of $150^{\circ} \mathrm{C}$ tensile strength, modulus of elasticity, tensile strength, strength coefficient and hardening of the exponent strain decreases but the elongation and plastic strain ratio increases. Formation under temperature $150^{\circ} \mathrm{C}$ material properties does not show large differences due to changes in temperature formation. In the draw bending test, spring back is reduced at temperatures of $150^{\circ} \mathrm{C}$ to $200^{\circ} \mathrm{C}$.

Jin et al, (2002) research on bending systems to realize high precision V-bending. The important point of this system is that the workpiece has been released before the punch reaches the final target position. Using this method can collect data, calculate material properties and predict the final target position. This position is determined by considering spring back after it is released. However, Springbank is not constant due to differences in material properties on each 
workpiece. In the proposed system, material properties: stress flow, Young's modulus, and hardening ratio are calculated based on information from the load, slope angle and spring back at the pre-release stage for the determination of suitable bending conditions.

\subsection{Bending}

Bending is a manufacturing process that can cause defects in metals by plastic deformation due to changes in material shape. This material is stressed above the yield strength limit but below the tensile strength. In general, bending refers to deformation around only one axis. Bending is a flexible process with a variety of different forms that can be produced even by using standard set dies or brake bending. Material is placed on dies and placed in a "stop" position by placing hold-downs. The upper part is pressed, with ram shaped punch pressing against the plate and forming a bending-v. Bending is done using press brakes that have a press capacity of 20 - 200 tons according to the given application (Diege, 2002).
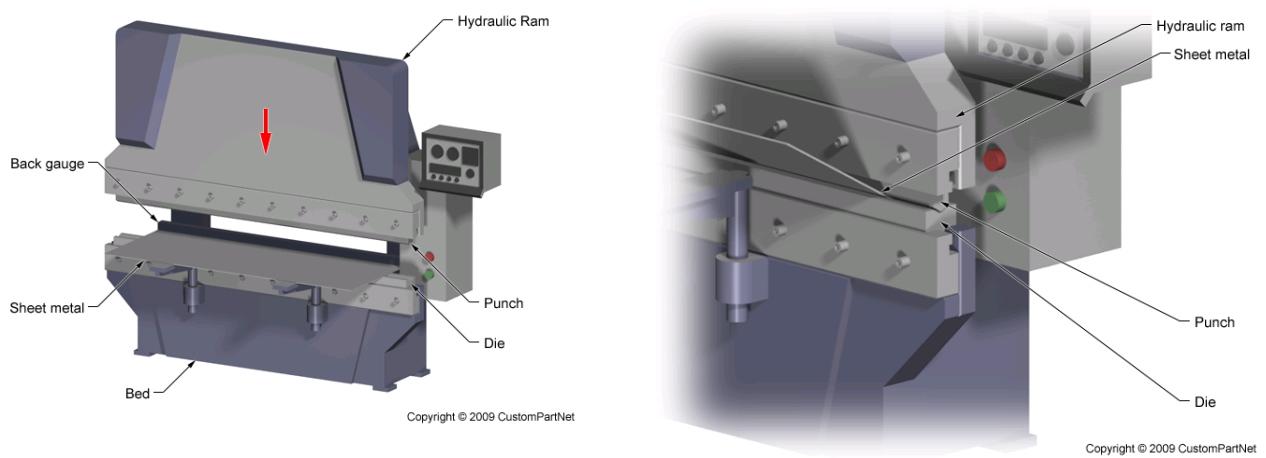

Figure 1. Press Brake (Open and Closed)

In the process of strengthening the construction of the vehicle body, a certain process is needed so that the sheet plates can be hard/strong. One way to harden it is by bending it. Several vehicle bodies are made to have grooves or nuts around the body. This is caused by changes in metal crystals, such as slips and deformation. The process of becoming stronger and harder is known as the work hardening process. This process is mostly carried out on the strengthening and hardening of metals, for example, the manufacture of stainless steel plates, aluminum plates (Gunadi, 2008).

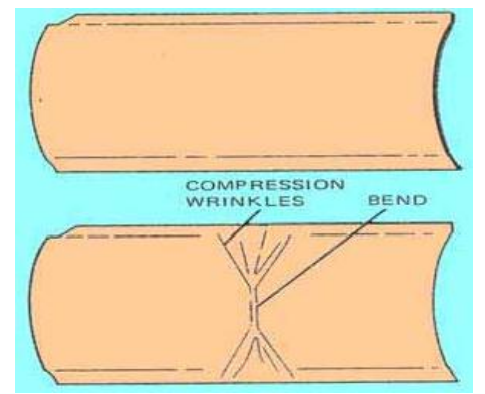

Figure 2. Bending Parts have stronger construction

In recent years, various experimental techniques have been developed to study the character of spring back on sheet metal, the most popular and often used in cylinder bending procedures are U-bending and V-bending. This method is very interesting because the level of the magnitude of spring back can easily be measured (Livatyali et al, 2001).
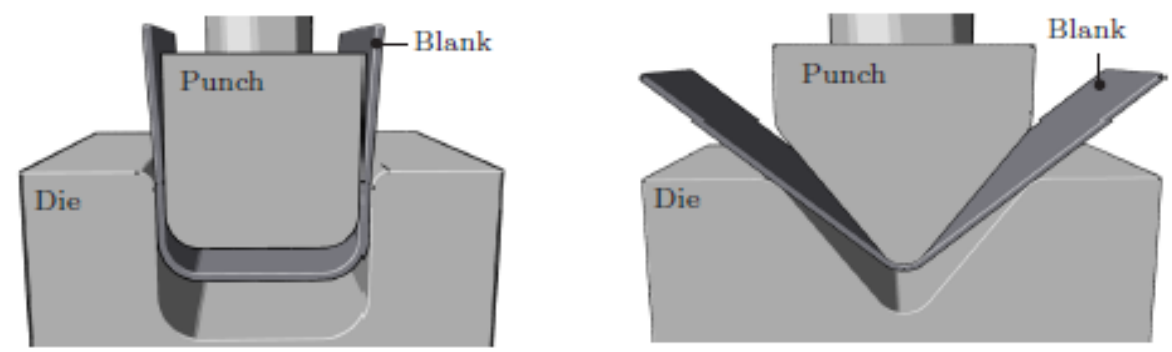


\section{a. U-Bending}

b. V-Bending

Figure 3. Simulation of U-Bending dan V-Bending form

\subsection{Heat Treatment}

The heat treatment process is a heating process on a solid metal to obtain the desired properties of the metal with certain limits. Steel can be heat treated to increase or reduce the hardness and tensile strength of steel. To increase the hardness of steel, hardening is carried out and tempering is used to increase the elasticity of the steel. Heat treatment is a combination of the process of applying heat to metals or alloys in a solid-state to a certain temperature and holding time, then followed by an appropriate cooling process so that the physical and mechanical properties of steel are obtained.

Steel that has been heat treated will produce the following benefits:

1. Increased hardness and strength of steel.

2. Regular physical and mechanical properties such as tenacity, corrosion resistance.

3. Raises magnetic and electrical properties in steel.

4. Improved grain size in steel.

\subsubsection{Annealing Process}

An annealing process is the treatment of heat on a material where the material is heated at a certain temperature and cools it slowly to room temperature. Annealing process carried out on sheet metal to obtain certain characteristics as well as a guarantee that the material can be formed properly by applicable standards. The formability of sheet metal is largely determined by the process of making the material which includes the heat treatment conditions it experiences (Prabhudev, 1988).

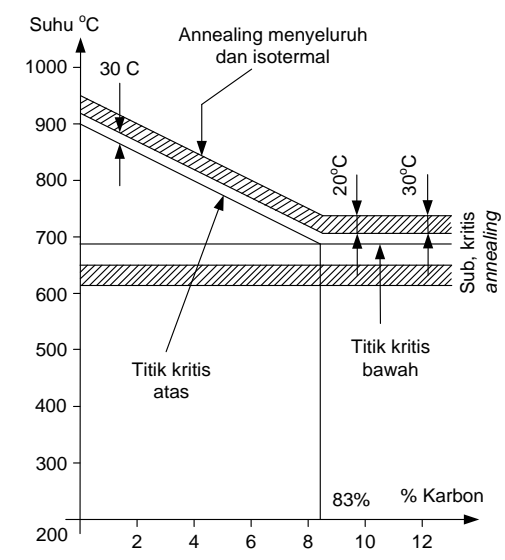

Figure 4. Annealing Temperature on steel

The purpose of annealing is to eliminate residual stress, reduce tensile strength, yield strength, hardness and increase the ductility of sheet metal that has undergone a cold reduction process, reduce the homogeneity of chemical composition, smooth grain size, reduce gas content in metals, this is a requirement for obtaining parameters good formability (Van Vlack, 1984).

\subsubsection{Holding Time}

Temperature holding for some time (holding time) aims to make the carbon contained in the carbide can dissolve into the austenite phase evenly and the temperature received on the surface and the inside of the steel evenly. The time needed to hold the temperature (holding time) depends on the type of steel that is given heat treatment.

\subsection{Spring back}


In the sheet metal forming process, the plate will be pressed to produce plastic deformation, when bending is removed there will be changes in shape or deviation of the die surface used for pressure, this is because the plate has elastic properties so that some of the deformations will return a little to a certain point. Deviation of shape and size due to the elasticity of this material is known as spring back, or residual elastic strain in the bending region when bending is removed which causes deviation in the shape of sheet metal to the shape of dies. Springback always occurs in sheet metal forming, for that reason needs to be considered because its influence is very important for changes in shape and size in the final product produced (H. Livatyali et al, 2001).

Springback can be observed in the bending process where the bending angle when bending is released (after spring back occurs) will be greater than the bending angle when bending is carried out on the plate, while the bending radius on the plate when bending is released (after occur spring back) is greater than when bending is done. Springback not only occurs in thin plates or flat plates, but also occurs in the form of the solid shaft, wire, rod with a certain area, and the pipe. In practice spring back can be reduced by overbending, ie the bending angle is smaller than required(Marciniak, 2002).

The spring back angle can be defined as shown in Figure 5, namely the plate's angle after the bending process - the clamp's angle.

Where is:

$$
\Delta \theta=\theta_{\mathrm{s}}-\theta_{\mathrm{C}}
$$

$\Delta \theta=$ spring back angle

$\theta_{\mathrm{S}}=$ bending angle after spring back

$\theta_{\mathrm{C}}=$ clamp angle

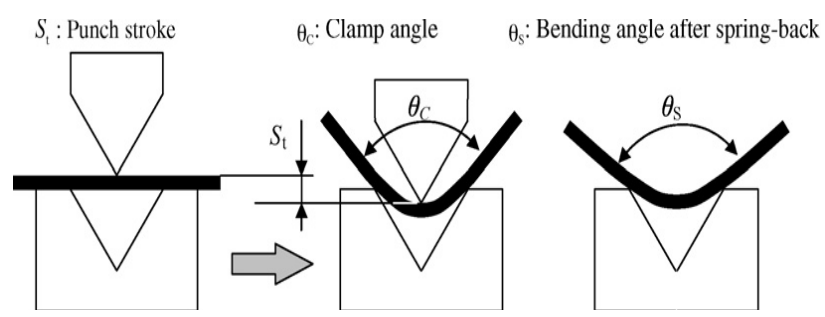

Figure 5. Plate change in the spring back prediction theory

\subsection{Hardenability}

The hardness of a material can be defined as the resistance of the material to the compressive force of other materials which is harder. The emphasis can be in the form of a scratching mechanism, reflection or indentation of hard material on a specimen surface (Yuwono, 2009).

\subsubsection{Mikro Vickers Method}

In this test, the metal surface is first pressed with a diamond pyramid-shaped indenter which is essentially square. The magnitude of the angle between the faces of the facing pyramid is 1360 VHN Vickers hardness. Vickers hardness is the number of strength of the test material against loading in each cross-sectional area of the area that receives loading.

$$
V H N=\frac{2 \sin \left(\frac{\theta}{2}\right)}{d^{2}} P=\frac{1,9544 P}{d^{2}}
$$

Where is :

$\mathrm{P}=$ compressive load given $(\mathrm{kg})$

$\mathrm{h}=$ long diagonal trampled $(\mathrm{mm})$

$\theta^{0}=$ penetrator peak angle $=136^{0}$ 
One of the standard tests for hardness testing is the Vickers hardness test. The advantages of testing using the Vickers method are (1) Objects with the same stress hardness can be determined not only for soft materials but also for hard materials; (2) With a small amount of pressure the experimental material will damage less; (3) Meticulous measurement of violence; (4) Hardness of thin workpieces or thin surface layers can be measured by choosing a relatively small force.

In this study using the micro Vickers method, because to find out how much the hardness value on the surface of the test specimen results from the annealing process so that the required loading is also relatively small ranging between 10 to $1000 \mathrm{gf}$.
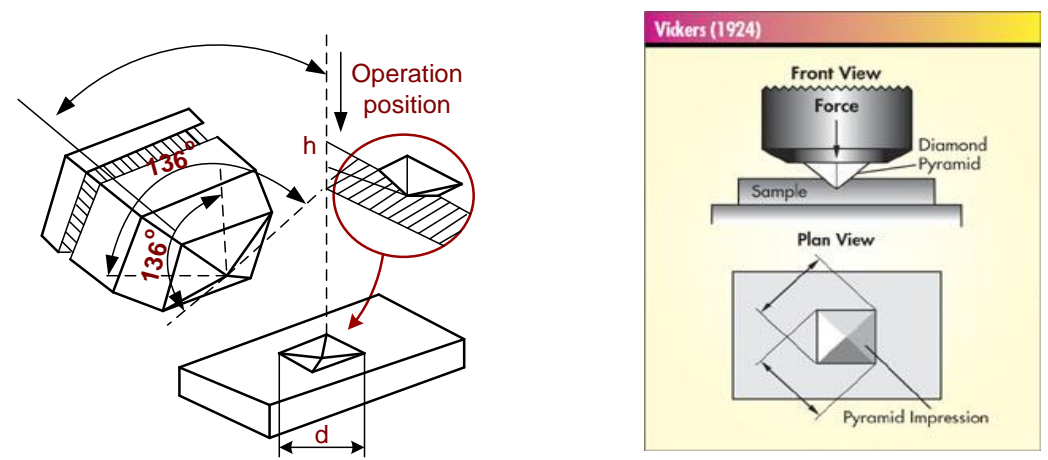

Figure 6. Schematic principle of identing with Vickers Method

\subsection{Microstructure}

The choice of steel raw material is determined by the alloy composition factor. The composition factor can influence the physical and mechanical properties and microstructure. The microstructure can interpret the violence and the material. Microstructure analysis is one part of physical metallurgy that can analyze the microstructure of steel due to heat treatment and mechanical treatment which results in grain shape which can later improve the physical and mechanical properties of steel if a material is heated to a certain temperature. Physical metallurgy is the knowledge of metallography, the constitution of the metal and its structure and its alloys are studied using an electron microscope or optical microscope.

The physical and mechanical properties of a material depend on the microstructure of the material. Microstructures in metals are shown by their size, shape, and orientation, the number of phases, proportions, and behavior in which they are arranged or distributed. The microstructure of the alloy depends on several factors such as the alloying element, concentration and heat treatment given.

\section{Research Methods}

\subsection{Research Conceptual Framework}

The study was conducted on the results of the commercial steel plate bending process by using a tensile-press test machine where the plates before bending were subjected to annealing treatment with temperature variations of 710,820 and $930^{\circ} \mathrm{C}$ and holding time of 60 minutes. With cooling in the furnace allows the workpiece to experience softening because the grain structure is increasingly regular due to recrystallization. The final annealing effect on material hardness and spring back results from V-bending plates. 


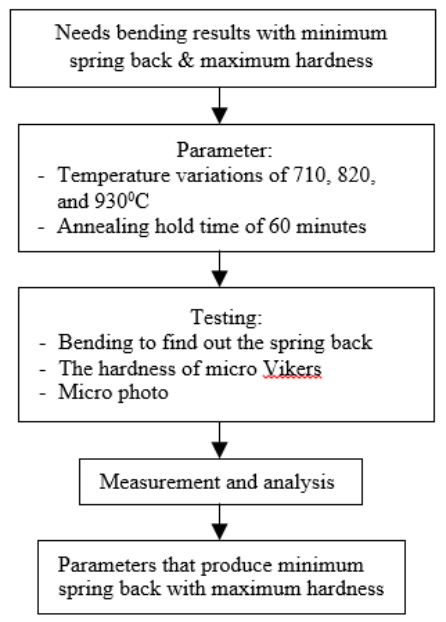

Figure 7. Research Conceptual Framework

Annealing process changes the microstructure and mechanical properties of the material that affects the hardness and bending results of spring back, to produce a minimum spring back with maximum hardness.

\subsection{Research Methods}

The research method used in solving this problem is a research method using experimental methods. Where the related variables will be applied in the experiment as a follow-up to the problem statement that has been described thoroughly. The experimental results obtained are not a final answer but as a source of data that must be processed and analyzed for proof of the hypotheses that have been made.

\subsection{Making Specimens}

\subsubsection{Making Specimen Dimension}

This study uses specimens made of commercial steel plates, with a size of $0.8 \times 50 \times 100$ $\mathrm{mm}$.
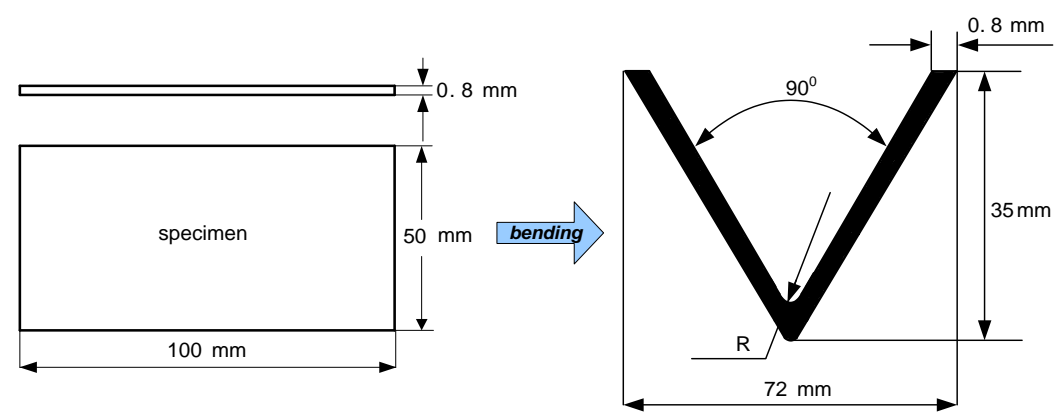

Figure 8. Specimen Dimension

\subsubsection{Making Punch and Dies} machine.

To bend the plates, dies and punches are used which are installed in a push-pull test 


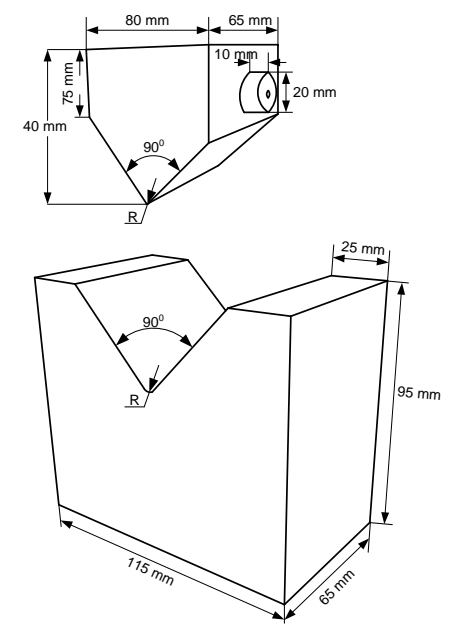

Figure 9. Dimension of Punch and Dies

\subsection{Testing Process}

a. Experiments in annealing with temperature variations of 710,820 and $930^{\circ} \mathrm{C}$ and holding time of 60 minutes.

b. Experiments are bent to see the spring back.

c. The bending experiment was tested hardness by using Vickers.

d. Experiments on microstructure testing.

e. Data retrieval.

\subsection{Research Design}

The design of this study was made based on variables that are correlated with each other, namely experiments without experiencing annealing process and experiments undergoing annealing process, then the specimen is bent to determine the angle of spring back and hardness tested. The data obtained will be designed in table form.

Table 1. Research Design

\begin{tabular}{|c|c|c|c|c|}
\hline $\begin{array}{l}\text { Temperatur } \\
\text { Anil } 15 \text { menit }\end{array}$ & Springback & Kekerasan & Struktur Mikro & Keterangan \\
\hline $710^{\circ} \mathrm{C}$ & $\mathrm{Y}_{11}$ & $\mathrm{Y}_{12}$ & $\mathrm{Y}_{13}$ & \\
\hline $820^{\circ} \mathrm{C}$ & $\mathrm{Y}_{21}$ & $\mathrm{Y}_{22}$ & $\mathrm{Y}_{23}$ & \\
\hline $930{ }^{\circ} \mathrm{C}$ & $\mathrm{Y}_{31}$ & $\mathrm{Y}_{32}$ & $\mathrm{Y}_{33}$ & \\
\hline $\begin{array}{l}\text { Raw Materials } \\
\text { Tanpa a Prlakuan } \\
\text { Panas }\end{array}$ & $\mathrm{Y}_{41}$ & $\mathrm{Y}_{42}$ & $\mathrm{Y}_{43}$ & \\
\hline
\end{tabular}

\section{RESEARCH RESULTS AND DISCUSSION}

\subsection{Steel Plate Composition Test}

The chemical composition of steel greatly influences steel properties such as toughness, hardness, and strength. The sample used in this study is commercial steel plates with chemical composition determined by the spark oes test method including commodity plate essers.

Table 2. Chemical Composition of Steel Plates

\begin{tabular}{|c|c|c|c|c|c|c|c|c|c|}
\hline \multicolumn{10}{|c|}{ Unsur (\%) } \\
\hline C & Si & S & P & Mn & Ni & Cr & Mo & V & Cu \\
\hline 0.0004 & $<0.0001$ & 0.007 & 0.019 & 0.071 & 0.009 & 0.019 & 0.002 & 0.001 & 0.012 \\
\hline \multicolumn{10}{|c|}{ Unsur (\%) } \\
\hline W & Ti & Sn & Al & Pb & Nb & Zr & Zn & Fe & \\
\hline$<0.0001$ & 0.051 & 0.002 & 0.047 & 0.002 & 0.002 & 0.001 & 0.001 & 99.77 & \\
\hline
\end{tabular}

The results of the composition test are intended to determine the elements contained in the material. The table above shows the carbon element of $0.0004 \%$, seen from the equilibrium diagram of the iron and carbon plates used, including the type of hypoeutectoid steel. 


\subsection{Bending Test}

The data of the V-bending test results are obtained from the tensile-press test equipment on the raw material plate and the annealing results. The average time of specimen suppression speed is $0.266 \mathrm{~mm} / \mathrm{sec}$. with a holding time of 1 minute.

Tabel 3. Steel Plate V-Bending Test Results

\begin{tabular}{|c|c|c|c|c|}
\hline No & Spesimen & $\begin{array}{c}\text { Area } \\
\mathrm{mm}^{2}\end{array}$ & $\begin{array}{c}\text { Max. Force } \\
\text { N }\end{array}$ & $\begin{array}{c}\text { Bending Strengh } \\
\text { Mpa }\end{array}$ \\
\hline 1 & Raw Material & 40 & 62500 & 117187.5 \\
\hline 2 & $710^{\circ} \mathrm{C}$ & 40 & 61750 & 115781.25 \\
\hline 3 & $820^{\circ} \mathrm{C}$ & 40 & 61550 & 115406.25 \\
\hline 4 & $930^{\circ} \mathrm{C}$ & 40 & 61225 & 114796.88 \\
\hline
\end{tabular}

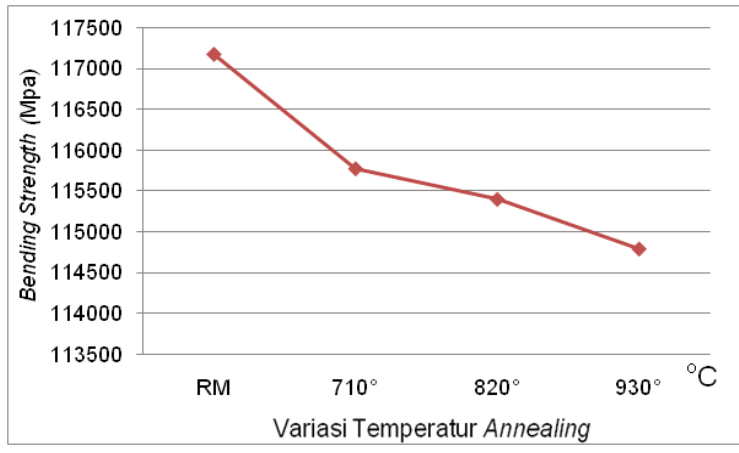

Figure 10. Graph of Effect of Temperature Variation Annealing Results V-Bending.

Figure 10 shows the bending strength value of the specimen in $117187.5 \mathrm{MPa}$ raw material but after being given heat treatment the bending strength is significantly reduced. At $7100 \mathrm{C}$ annealing temperature of bending strength $115781.25 \mathrm{Mpa}$, the annealing temperature of $8200 \mathrm{C}$ bending strength of $115406.25 \mathrm{Mpa}$, the annealing temperature of $9300 \mathrm{C}$ bending strength of $114796.88 \mathrm{Mpa}$, this phenomenon is supported by the results of hardness test where the higher the annealing treatment, the less hardness is reduced.

\subsection{Spring back Results of V-Bending Steel Plate}

Spring back angle measurements are carried out on each side of the specimen V-bending results by using auto cad software where the specimen is first scanned for pictures. On each side, the bent specimen is then given a point and connected to the other side to determine the spring back. In this study, each specimen made six angles then taken on average. The spring back angle comparison is 900 adjusting the dimensions of the punch and dies V-bending.

Table 4. Springback Angle Results of V-bending

\begin{tabular}{|c|c|c|c|c|}
\hline No & Spesimen & $\begin{array}{c}\text { Sudut Setelah } \\
\text { Bending }\left({ }^{\circ}\right)\end{array}$ & $\begin{array}{c}\text { Sudut } \\
\text { Clamp }\left({ }^{\circ}\right)\end{array}$ & $\begin{array}{c}\text { Sudut } \\
\text { Springback }\left({ }^{\circ}\right)\end{array}$ \\
\hline 1 & Raw Material & 92.175 & 90 & 2.175 \\
\hline 2 & $710^{\circ} \mathrm{C}$ & 91.703 & 90 & 1.703 \\
\hline 3 & $820^{\circ} \mathrm{C}$ & 91.365 & 90 & 1.365 \\
\hline 4 & $930^{\circ} \mathrm{C}$ & 90.838 & 90 & 0.838 \\
\hline
\end{tabular}




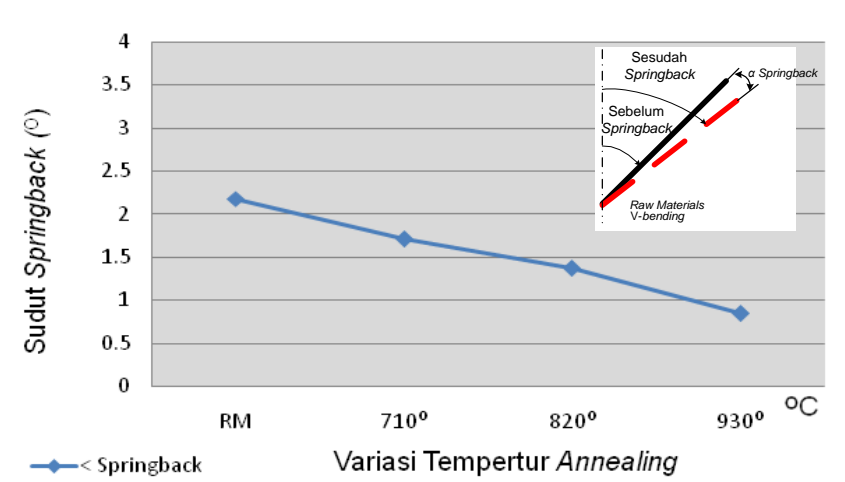

Figure 11. Springback Graph V-Bending Results Against The Effect of Annealing and Raw Material Temperature Variations

From the graph above it can be seen that the raw material specimens from the V-bending result have a spring back angle value of $2.175^{\circ}$ or $2.4 \%$ greater than the punch and dies angle of $90^{\circ}$. Specimens that are heat-treated at $710^{\circ} \mathrm{C}$ have a spring back angle value of $1.703^{\circ}$ or decrease $0.5 \%$ towards the spring back raw angle material, as well as $1.9 \%$ greater to the punch angle and dies $90^{\circ}$.

Specimens that were heat-treated at $820^{\circ} \mathrm{C}$ had a spring back angle value of $1.365^{\circ}$ or decreased $0.9 \%$ to the angle of the spring back raw material and decreased $0.4 \%$ to the spring back angle V-bending of the $710^{\circ} \mathrm{C}$ heat treatment specimen, and $1.5 \%$ greater to the punch and dies angle of $90^{\circ}$.

Specimens that were heat-treated at $930^{\circ} \mathrm{C}$ had a spring back angle value of $0.838^{\circ}$ or decreased $1.6 \%$ to the spring back angle of raw material and decreased $0.9 \%$ to the spring back angle of V-bending of $710^{\circ} \mathrm{C}$ specimens, decreased by $068 \%$ to the spring back angle of $\mathrm{V}$ bending of $820^{\circ} \mathrm{C}$ specimens, and $0.9 \%$ greater towards punch angles and 900 dies.

Figure 11, shows the spring back angle decreases, this is due to the influence of the temperature of the heater, where the higher the heating temperature, the tenacity increases so that the plates have good formability.

\subsection{Steel Plate Hardness Test Results}

\subsubsection{Pre-Bending Steel Plate Hardness Test Results}

Hardness testing was carried out using the micro Vickers method at a load of $50 \mathrm{gf}$ with a holding time of 10 seconds with the same point distance.

Table 5. Hardness Test Results on Plates

\begin{tabular}{|c|c|c|c|c|c|}
\hline No & Spesimen & \multicolumn{3}{|c|}{ Kekerasan (HV) } & Rata-rata \\
\hline 1 & Raw Materials & 142 & 128 & 159 & 143.00 \\
\hline 2 & $710^{\circ} \mathrm{C}$ & 132 & 135 & 139 & 135.33 \\
\hline 3 & $820^{\circ} \mathrm{C}$ & 136 & 131 & 131 & 132.67 \\
\hline 4 & $930^{\circ} \mathrm{C}$ & 111 & 121 & 128 & 120.00 \\
\hline
\end{tabular}

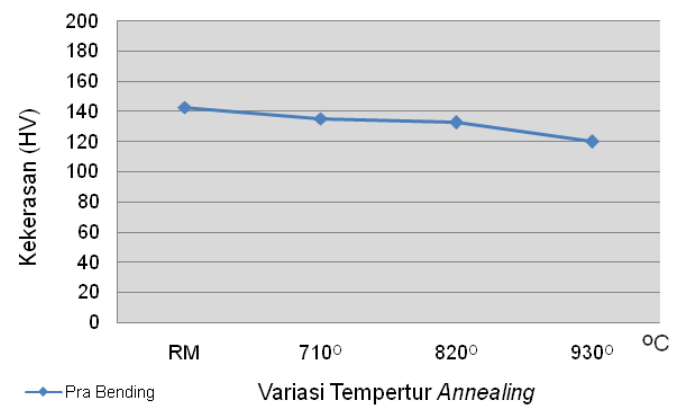

Figure 12. Graph Effect of Annealing Temperature Variations on Hardness in Pre-Bending Steel Plates 
From the graph above it can be seen that the raw material specimen has a hardness value of $143.00 \mathrm{HV}$. Specimens that were heat-treated at $710^{\circ} \mathrm{C}$ had a hardness value of $135.33 \mathrm{HV}$ or decreased by $5.4 \%$ of the raw material.

The hardness value of specimens undergoing heat treatment process up to the temperature of $820^{\circ} \mathrm{C}$ has a hardness value of $132.67 \mathrm{HV}$ or decreased $7.2 \%$ on raw material, and decreased $1.9 \%$ on specimen $710^{\circ} \mathrm{C}$.

The hardness value of specimens undergoing heat treatment process at a temperature of $930^{\circ} \mathrm{C}$ has a hardness value of $120.00 \mathrm{HV}$ or decreased $16.1 \%$ to raw material, and decreased by $11.3 \%$ to $710^{\circ} \mathrm{C}$ specimens and decreased $9.6 \%$ to $8200 \mathrm{C}$ specimens.

\subsubsection{V-Bending Steel Plate Hardness Test Results}

Hardness testing was carried out using the micro Vickers method at a load of $50 \mathrm{gf}$ with a holding time of 10 seconds with the same point distance. For the plate of bending results the Vickers microhardness test is carried out on the outer bends where before the hardness test is carried out the specimen is first given a resin so that the specimen is not shaken when pressed by the indenter.

Table 5. V-Bending Plate Hardness Test Results

\begin{tabular}{|c|c|c|c|c|c|}
\hline No & Spesimen & \multicolumn{3}{|c|}{ Kekerasan (HV) } & Rata-rata \\
\hline 1 & Raw Materials & 159 & 171 & 191 & 173.67 \\
\hline 2 & $710^{\circ} \mathrm{C}$ V-bending & 180 & 139 & 145 & 154.67 \\
\hline 3 & $820^{\circ} \mathrm{C}$ V-bending & 132 & 140 & 128 & 133.33 \\
\hline 4 & $930^{\circ} \mathrm{C}$ V-bending & 108 & 121 & 147 & 125.33 \\
\hline
\end{tabular}

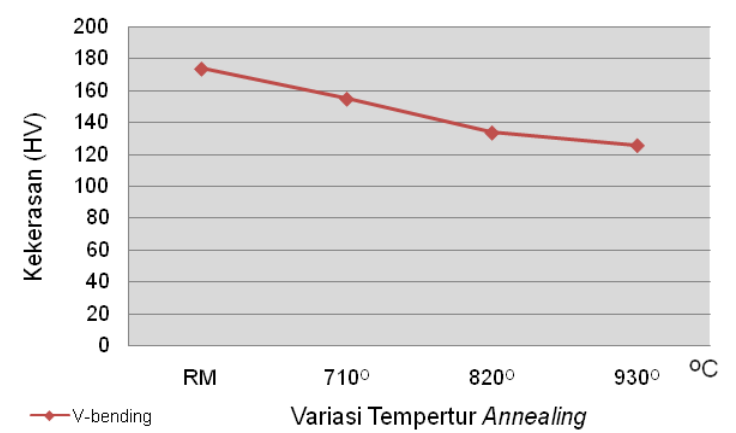

Figure 13. Graphic Effect of Annealing Temperature Variations on Hardness in Steel Plate

From the graph above it can be seen that the V-bending raw material specimen has a hardness value of $173.67 \mathrm{HV}$. Bending specimens that were annealed at $710^{\circ} \mathrm{C}$ had a hardness value of $154.67 \mathrm{HV}$ or decreased by $10,940 \%$ to the raw material.

The hardness value on bending specimens that experienced annealing process up to $820^{\circ} \mathrm{C}$ had a hardness value of $133.33 \mathrm{HV}$ or decreased by $23,228 \%$ against raw material, and decreased by $13,797 \%$ against $710^{\circ} \mathrm{C}$ specimens.

The hardness value on bending specimens that underwent annealing process up to $930^{\circ} \mathrm{C}$ had a hardness value of $125.33 \mathrm{HV}$ or decreased by $27.8 \%$ against raw material, and decreased by $18,969 \%$ against $710^{\circ} \mathrm{C}$ bending specimens and decreased by $6 \%$ against $820^{\circ} \mathrm{C}$ bending specimens. 


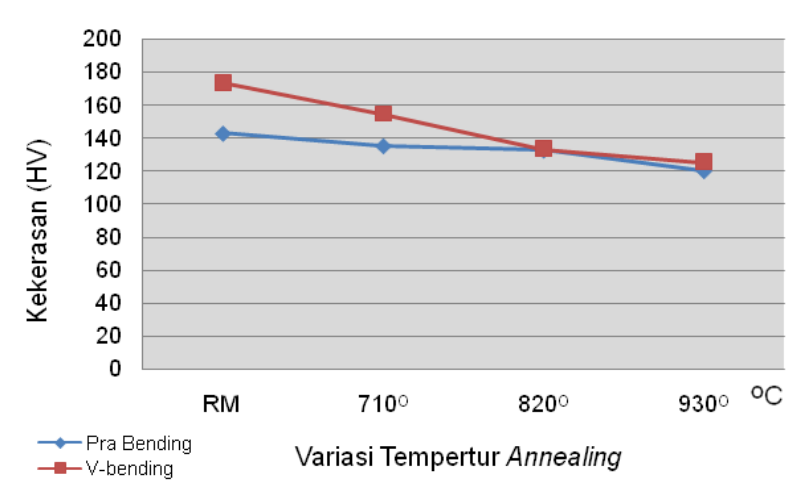

Figure 14. Graphic Comparison of Plate Hardness and V-Bending Results From Annealing Temperature Variations

From the graph above it can be seen that the pre-bending raw material specimen has a hardness value of $143.00 \mathrm{HV}$. After the raw material specimen was bent the hardness increased by $173.67 \mathrm{HV}$ or increased by $21.4 \%$. Bending raw material specimens are one part of cold work. As a result of cold working, the dislocation increases so that the movement of the dislocation becomes more difficult which results in the material getting stronger when the material is burdened from the outside.

The hardness value in the pre-bending specimen undergoing annealing temperature of $710^{\circ} \mathrm{C}$ has a hardness value of $135.33 \mathrm{HV}$. At this temperature the material is heated at a recovery temperature below the recrystallization temperature then the material will undergo polygonization which is rearranging the dislocation arrangement so that it becomes regular. After the specimen is bent the hardness is 154.67 or has an increase of $14.3 \%$ due to excessive dislocation remaining in the slip plane after the material is bent.

The hardness value in the pre-bending specimen undergoing annealing process up to $820^{\circ} \mathrm{C}$ has a hardness value of $132.67 \mathrm{HV}$. After the specimen is bent the hardness is $133.33 \mathrm{HV}$ or has increased by $0.5 \%$.

The hardness value in the pre-bending specimen undergoing annealing process up to a temperature of $930^{\circ} \mathrm{C}$ has a hardness value of $120.00 \mathrm{HV}$. After the specimen is bent the hardness is $125.33 \mathrm{HV}$ or has increased by $4.4 \%$.

For V-bending hardness, the hardness value increases significantly. This phenomenon is caused by the material undergoing plastic deformation caused by an atom shift or dislocation (defective lines in the arrangement of atoms) by shear stress. The process of becoming stronger and harder is known as the work hardening process.

The greatest hardness value is at $710^{\circ} \mathrm{C}$ annealing temperature which is $154.67 \mathrm{HV}$ or increased by $14.3 \%$ after the plate is bent. The lowest hardness value is at an annealing temperature of $930^{\circ} \mathrm{C}$ which is $125.33 \mathrm{HV}$ or an increase of $4.4 \%$ after the plate is bent.

\subsection{Micro Photo Test Result}

Micro testing was observed under a microscope at a magnification of 400x. The area observed was the surface of each specimen. Then do metallographic photo-taking with an optical microscope. Metallographic testing is carried out to determine the microstructure contained in the specimen, where the results of this metallographic test are used to support the results of the Vickers microhardness test. 


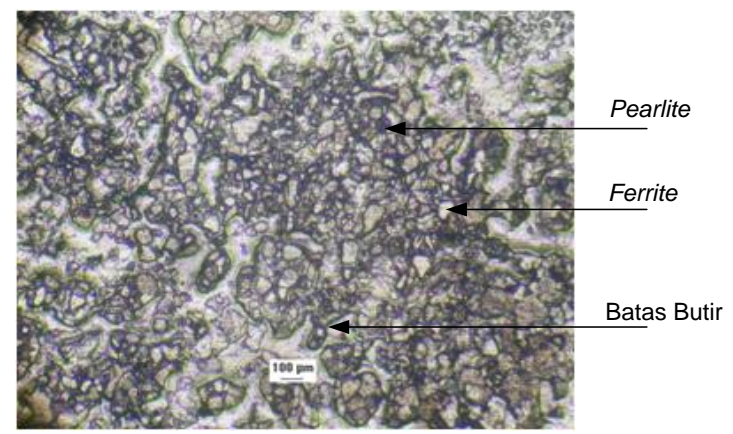

Figure 15. Microstructure of Raw Material Plates

The raw material phases formed based on observations are the white ferrite $(\alpha)$ phase and the black pearlite phase, this shows that the raw material specimens can be heat treated because the ferrite content is still large. The microstructure of the raw material is dominated by white (bright) ferrite grains, while the pearlite phase is less (dark). Ferrite grains tend to be finer while pearlite grains are coarser. Pearlite grains tend to be hard because they contain carbon, whereas ferrite grains tend to be soft. Also, by considering the iron and carbon equilibrium diagram, this low carbon steel is a type of hypo eutectoid steel because the percentage of carbon alloy elements does not exceed $0.8 \%$.

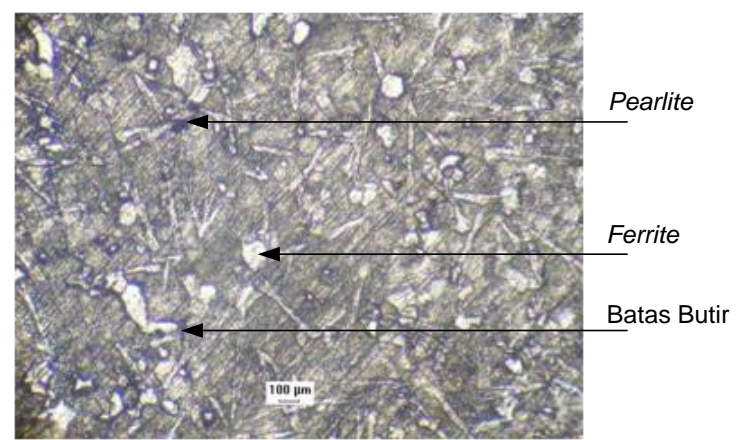

Figure 16. Microstructure on The V-Bending Plate Material

Figure 16, is an image of a microstructure in a raw material specimen subjected to $\mathrm{V}$ bending which is photographed on the outside of the bending region, due to the applied force the granules are elongated/flat. This phenomenon is caused by the material undergoing plastic deformation due to atomic displacement or dislocation (line defects in the arrangement of atoms) by shear stresses due to cold work.

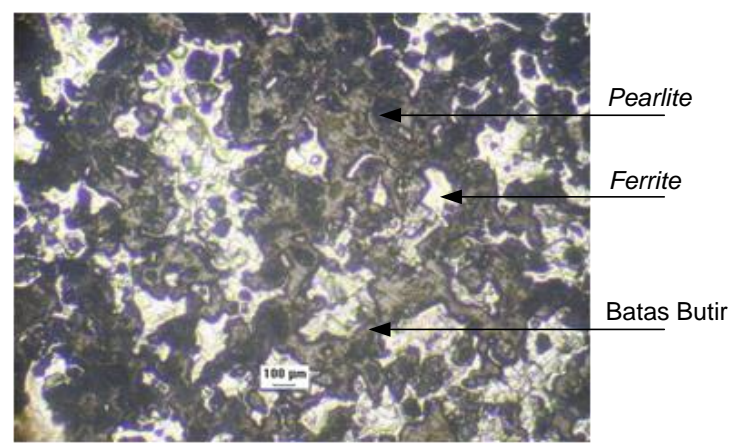

Figure 17. Microstructure of Plate with Annealing $710^{\circ} \mathrm{C}$ Temperature

In figure 17, the phases formed based on observations are the white ferrite $(\alpha)$ phase and the black pearlite phase. Heat treatment annealing with a temperature of $710^{\circ} \mathrm{C}$ is included below the recovery temperature or below the recrystallization temperature $\left(769^{\circ} \mathrm{C}\right)$, the material is polygonized, which is the rearrangement of the dislocation arrangement so that the arrangement of the atoms becomes orderly due to cold working. There was a grouping in the ferrite phase and the pearlite phase in the image above and the structure was larger. Crystal 
structure that occurs becomes larger than the raw material, this is due to the heat treatment process.

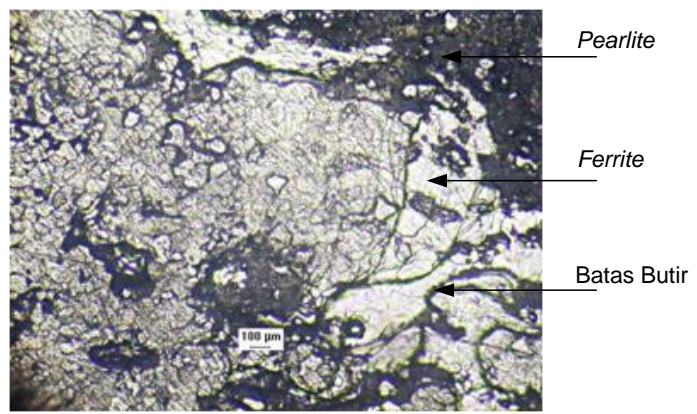

Figure 18. Microstructure of Plate with Annealing $710^{\circ} \mathrm{C}$ Temperature V-Bending Result

Figure 18 is a microstructure image of a $710^{\circ} \mathrm{C}$ annealing specimen undergoing $\mathrm{V}$ bending, photographed on the outside of the bending region. In the V-bending process, due to the applied compressive force, the granules are elongated/flat. This phenomenon is caused by the material undergoing plastic deformation due to atomic displacement or dislocation (line defects in the arrangement of atoms) by shear stress due to cold work. In the picture above, each ferrite granule is gathered together and so is the black pearlite granules.

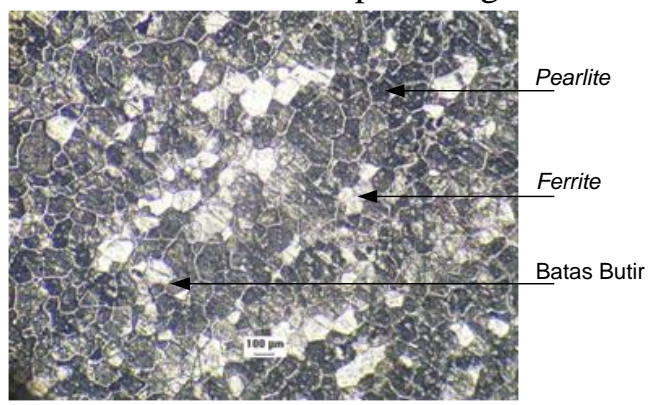

Figure 19. Microstructure of Plates with Annealing Temperature of $820^{\circ} \mathrm{C}$

In figure 19, the phases formed based on observations are the white ferrite $(\alpha)$ phase and the black pearlite phase. At this temperature the specimen includes heating at recrystallization temperature $\left(769^{\circ} \mathrm{C}\right)$, the material has entered the austenite + pearlite phase. At this temperature of grain sizing, the new core will grow to replace the old grains and produce uniform grain growth.

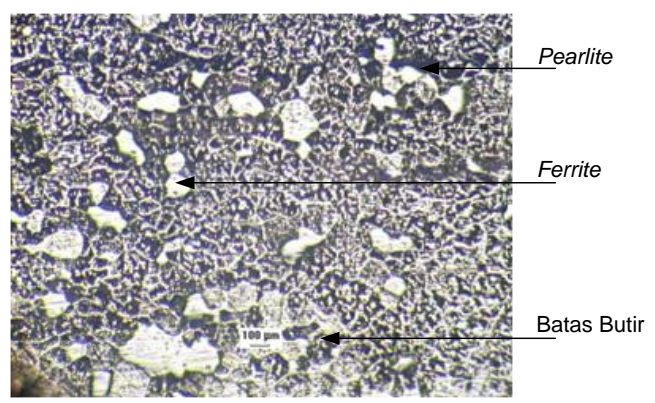

Figure 20. Microstructure of Plates with Annealing Temperature $820^{\circ} \mathrm{C}$ V-Bending Results

Figure 20 is a microstructure image of an $820^{\circ} \mathrm{C}$ annealing specimen undergoing $\mathrm{V}$ bending, photographed on the outside of the bending region. In the $\mathrm{V}$-bending process, the plates undergo compressive and tensile forces resulting in elongated grain structure. In the picture above you can see the ferrite granules clustered in bright white and there is a smooth growth of ferrite grains that surround the pearlite grains. This phenomenon is caused by the material undergoing plastic deformation due to atomic displacement or dislocation (line defects in the arrangement of atoms) by shear stress due to cold work. 


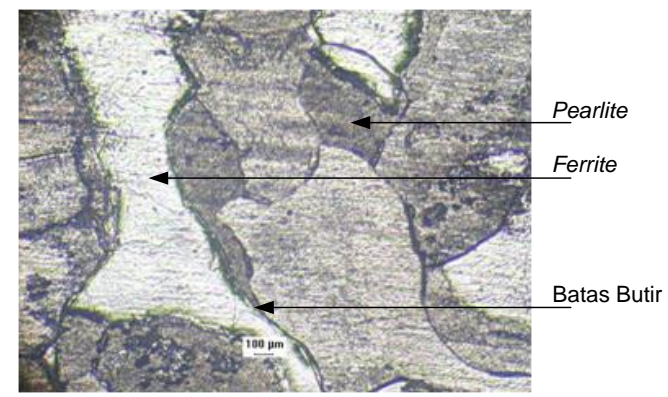

Figure 21. Microstructure in Annealing Temperature Plates $930^{\circ} \mathrm{C}$

In figure 21, the phases formed based on observations are the white ferrite $(\alpha)$ phase and the black pearlite phase. The annealing temperature of $930^{\circ} \mathrm{C}$ the growth of the grains grew even greater due to the full annealing temperature. At this temperature the specimen is already at austenite temperature, the driving force for grain growth is lower than the driving force for recrystallization. Grain growth will occur slowly at temperatures where recrystallization occurs easily. Grain growth is highly dependent on recrystallization and soon the grain area will be reached where the grain increases very quickly. In this condition, some grains in the material will begin to grow very quickly and enlarge at the expense of other grains due to the material being heated at higher temperatures. This phenomenon is known as excessive grain growth or replacement of fine grains by coarse grains or also called secondary recrystallization.

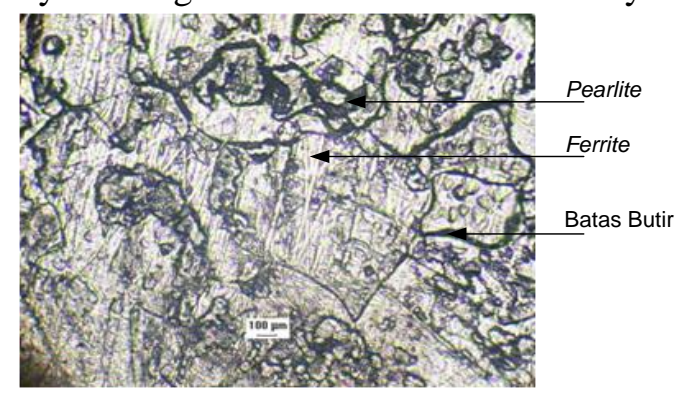

Figure 22. Microstructure of Plates with Annealing Temperature of $930^{\circ} \mathrm{C}$ V-Bending Results

Figure 22 is a microstructure image of a V-bending annealing specimen $930^{\circ} \mathrm{C}$, photographed on the outside of the bending region. In the V-bending process, the plates at the bottom of the compressive force so that the grain structure is elongated/flat. This phenomenon is caused by the material undergoing plastic deformation due to atomic displacement or dislocation (line defects in the arrangement of atoms) by shear stress due to cold work.

\section{CONCLUSIONS}

From the results of research that have been carried out on commercial steel plates that have been subjected to heat treatment annealing with variations in temperature of $710^{\circ} \mathrm{C}, 820^{\circ} \mathrm{C}$, $930^{\circ} \mathrm{C}$ and holding time of 60 minutes resulting in changes in spring back, hardness and microstructure of the $\mathrm{V}$-bending results.

1. The heat treatment process causes a change in hardness, the higher the heat treatment temperature, the lower the hardness because the grains grow and enlarge so that the grain boundaries are reduced. For the value of V-bending hardness, the hardness increases significantly.

2. The heat treatment process also causes changes in the microstructure from the flat shape and extends to the shape of the growth of new grains that have implications for changes in mechanical properties and formability of the workpiece.

3. The heat treatment process causes the spring back angle to decrease, the higher the heat treatment temperature, the lower the spring back angle because due to the heat treatment the plates get softer so that when the plate is plastically deformed, the elasticity of the small plate results in the spring back angle being smaller. 


\section{REFERENCES}

Advanced High Strength steel (AHSS) application Guideliness www. Worlddautosteel.org.

Amanto, Hari, \& Daryanto. (1999). Ilmu Bahan. Jakarta: PT. Bumi.

Budinski, KennethG. (1996). Engineering Material . Properties and selection. Fifth Edition. New Jersey Colombus, Ohio: Prentice Hall Upper Saddle Rivers.

Diegel Olaf. (2002). Complete Design Service, July 2002, The Fine-Art of Sheet Metal Bending. Gunadi. (2008). Teknik Bodi Otomotif. Departemen Pendidikan Nasional, Jakarta

H. Livatyali \& T. Altan .(2001). Prediction and elimination of springback in straight flanging using computer aided design methods. Part 1. Experimental investigations. Journal of Material Processing Technology, 117(1-2):262-268.

J.-T. Gau and G.L. Kinzel, (2001). An experimental investigation of the influence of the bauschinger effect on springback predictions. Journal of Material Processing Technology, 108(3):369-375.

Keum, Y.T \& B.Y. Han. (2002). Springback of FCC sheet in warm forming. Journal of Ceramic Processing Research. Vol. 3, No. 3, pp. 159 165. Korea

Lawrence, Van Vlack. (1991). Ilmu Bahan dan Teknologi Bahan. Jakarta:Erlangga.

Marciniak, Z., Duncan, J.L., Hu, S.J. (2002). Mechanics of Sheet Metal Forming, ButterworthHeinemann, London.

Mubarok Fahmi (2008). Metallurgy II. Metallurgy Laboratory Mechanical Enggineering Dep ITS-Surabaya.

Naceur. H, S. Ben Ellechi, J.L. Batoz. (2005). On The Design of Sheet Metal Forming Parameters for Springback Compensation. VIII International Conference on Computational Plasticity COMPLAS VIII E. Oñate and D. R. J. Owen (Eds) ( C CIMNE, Barcelona.

Ozturk F, S Toros, S Kilic dan M H Bas. (2009). Effects of cold and warm temperatures on springback of aluminium magnesium alloy 5083-H111. Department of Mechanical Engineering, Nigde University, Nigde, Turkey.

Peng Wu, Yuezhong Xu, Zhenxing Huang and Jiachao Zhang (2015). A review of preparation techniques of porous ceramic membranes. Journal of Ceramic Processing Research. Vol. 16, No. 1, pp. 102 106. Korea.

Sinaga Ramli, Puslitbang KIM-LIPI. (1995), Effek Variasi Temperatur Terhadap Perubahan Sifat Mekanik, Struktur Mikro pada Lembaran Pelat Baja Karbon Rendah Hasil Reduksi Dingin. ISSN 0852-002 X, PPI-KIM. 